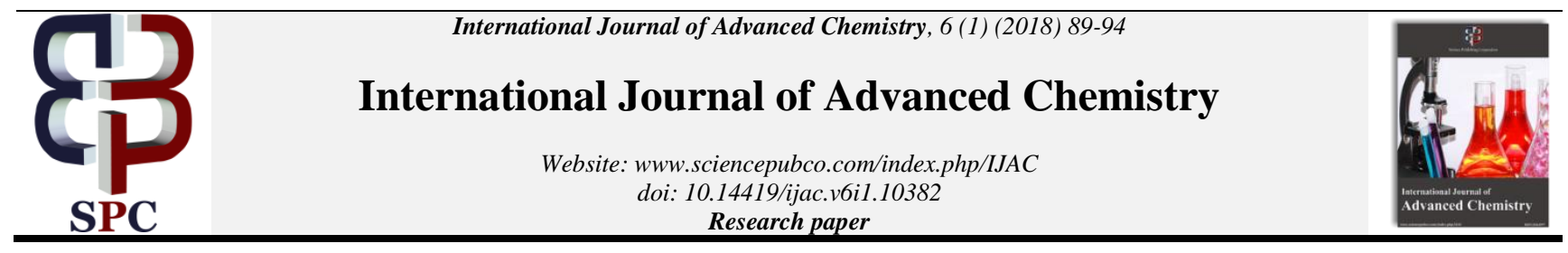

\title{
Interesting Mechanistic Approach for Nitrogen Heterocycles of Industrial Importance
}

\author{
N.D.Zargar ${ }^{1 *}$, K.Z.Khan ${ }^{1}$ \\ ${ }^{1}$ Department of Chemistry University of Kashmir Srinagar (190006) J\&K India \\ *Corresponding author E-mail:nded.1092@ rediffmail.com
}

\begin{abstract}
Nitrogen heterocycles have played an important role in different industrial sectors.Porphyrins the macrocyclic compounds containing pyrrole rings provide an extremely versatile platform with desired peripheral functionality and metal complexes to form the self assembly under varying reaction conditions. Haemoglobin an iron complex is responsible for binding molecular oxygen and transporting it to different sites. Mechanistically interesting N-heterocycles, Arylidene-1,3-indandione adducts (6) and (7) synthesized frequently are of immense pharmaceutical importance showing fungicidal and bactericidal activities. Nitrogen heteroatom phthalimide derivatives(8),(9) and (10) have been evaluated as possible potential prodrugs. A wide range of Nitrogen heterocycles have been synthesized for every imaginable use in dye and polymer industries.
\end{abstract}

Keywords:N-Heterocycles; Porphyrins; Selfassembly; Fungicidal; Pyrrole Rings; Phthalimide; Dye; Polymer; Indole; Triazolines.

\section{Introduction}

Heterocycles form the largest class of organic compounds. These are cyclic compounds with the ring containing carbon and at least one different atom like nitrogen,oxygen,sulphur etc.They are very widely distributed in nature with a variety of physiological activities associated with them .A great deal of research has been carried out to synthesize new heterocyclic compounds of medicinal and industrial importance.Thermolysis of triazolines $\left(1 \mathrm{a} ; \mathrm{NR}_{2}=\right.$ morpholino), yields a mixture of elimination products (1b) and the thiophene (1c;Pocar.D et,al 1977). Photochemical cycloaddition of 2,5-diphenyl-1,3,4-oxadiazole(1d) to 3-methyl benzothiophene results the formation of (Figure-2b) but in presence of iodine,the addition is reversed yielding the product (2c; Tashiro.M et.al 1977). $3 \mathrm{H}$ indole (2d) gets converted to the indole (3d) by intermolecular thermal rearrangement (Decodts.G et.al 1976)and the toluene p-sulphonyl hydrazone (1e) gets decomposed upon heating to indole quinone (2e; Abika.M.et.al 1977 and Takada.T et.al1977).

Keeping in view it was thought better to exploit the importance of certain N-heterocycles in varying fields of industry. Plausible mechanism for the formation of different compounds has also been proposed in this article.

\section{Discussion}

Nitrogen heterocycles form an important category of heterocyclc compounds. Pyridine,Pyrrole, Indole, Quinoline and a range of other N-heterocycles have been found distributed in nature as well as synthesized by new methods.They can be monocyclic or in fused heterocyclic system. (Finar.I.L,1986 and Suschitzky.H.et.al.1989).<smiles>c1ccncc1</smiles><smiles>c1cc[nH]c1</smiles><smiles>c1ccc2[nH]ccc2c1</smiles><smiles>c1ccc2ncccc2c1</smiles><smiles>c1cnc2[nH]cnc2c1</smiles>

Pyridine, Pyrrole, Indole, Quinoline, Purine<smiles>c1ccc(-c2nnn(-c3ccccc3)n2)cc1</smiles>

Diphenyl tetrazole<smiles>c1ccc(-c2n[nH]c3ccccc23)cc1</smiles>

Phenylindazole 
These nitrogen heterocycles have played a significant role in biology,medicine,industry and some other fields as well.Pyrrole a five membered monocyclic nitrogen containing heterocyclic compound has tremendous applications in the field of biology.Pyrrole rings form the building blocks of several biologically important pigments. Porphyrins the macrocyclic compounds containing four pyrrole rings linked by one carbon bridges. The molecules have a conjugated system of $18 \pi$ electrons as shown in the parent molecule porphine(Figure-1).

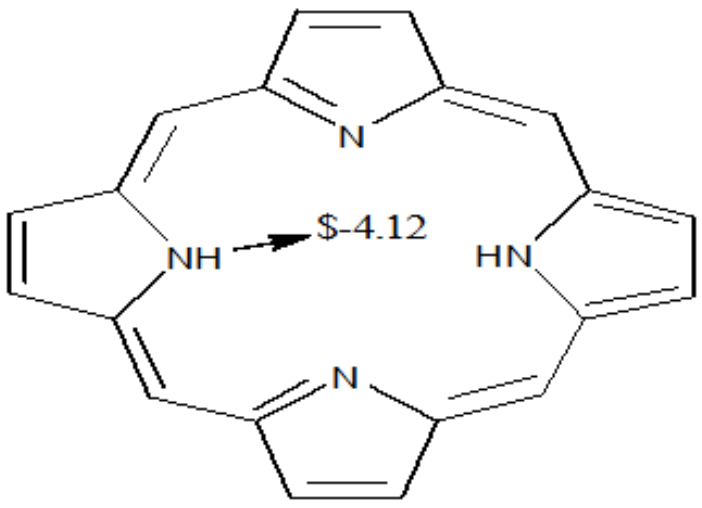

Fig. 1: Porphine.

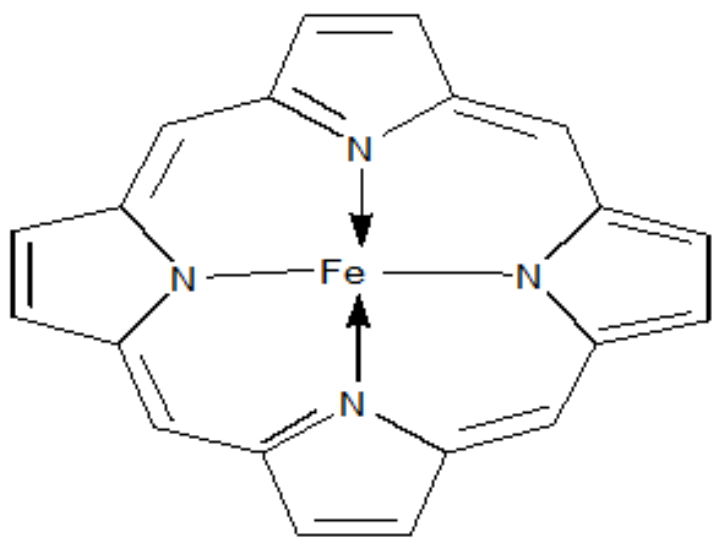

Fig. 1: (A) Iron Porphine Complex.

Dueto large size,excellent thermal stability,ease of synthesis,diversity of their coordination and catalytic chemistry (Anderson.H.L 1999, Loewe.J.S et.al 2002,Ogawa.K.et.al 2002, Seidel.S.R.et.al 2002 and Stang.P.J.et al 1997) porphyrins and metalloporphyrins have been found selectively an unexplored class of nanomaterials. Self assembly is an important technique in the synthesis of superstructures in biology,material science and chemistry.Lehn.J.M 1995, Whiteside.G.M.et.al 1995, D.S.Lawrence .et.al 1995 and Philip .D 1996).Porphyrins provide an extremely versatile platform with desired peripheral functionality and material complexes to form the self -assembly both in solution and solid state under different reaction conditions. The self assembly of porphyrin derivatives have been widely used in photoelectrical,photonic devices and as functional materials.(Alessio.E.et.al 2002 ,Linton.B et.al 1997,Burrel.A.K et.al 2000 and Susklie.K.S et.al.2000).

Porphine itself does not occur in nature but analogous compounds with various side chains on pyrrole rings are some of the most important life sustaining compounds of nature.Heme(Figure-2),for instance,the iron complex responsible for the red colour of arterial blood is present in red blood cells as a complex with a protein called globin and the complex is called haemoglobin.This complex is responsible for binding molecular oxygen and transporting it from lungs to all the cells of the body.The iron atom is complexed with four porphyrin nitrogens and has also two additional coordination sites, above and below the plane of the porphyrin ring.

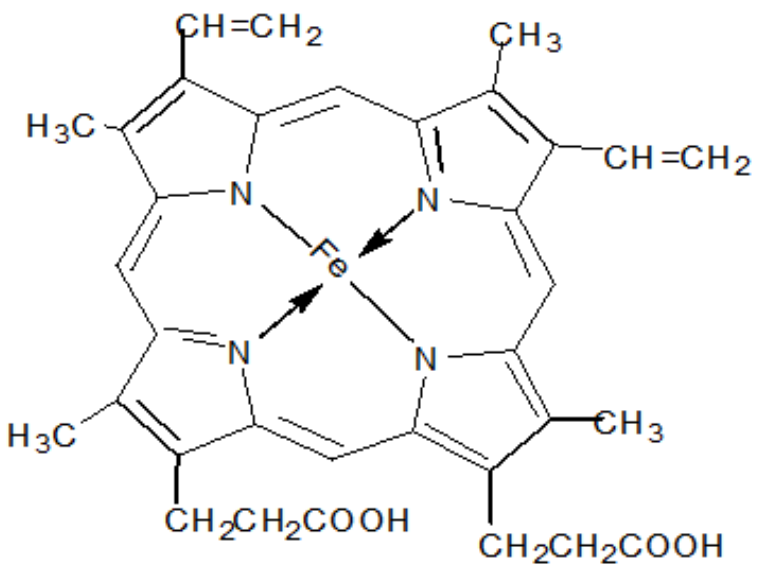

Fig. 2: Heme.

Chlorophyll, a magnesium complex of modified porphyrin is responsible for green colour of plants. This pigment is present in chloroplasts, one or more of which can be present in cells. Indole is an important member of fused nitrogen containing heterocycles. The indole ring system prevalent in a number of important natural products,is usually biosynthesized from the amino acid tryptophan (Figure-3),one of the building blocks of proteins.

Decarboxylation of tryptophan gives tryptamine(Figure-4).A number of compounds with this skeleton have a profound effect on brain and nervous system.Serotonin (Figure-5) is an example,a neurotransmitter active in the central nervous system.

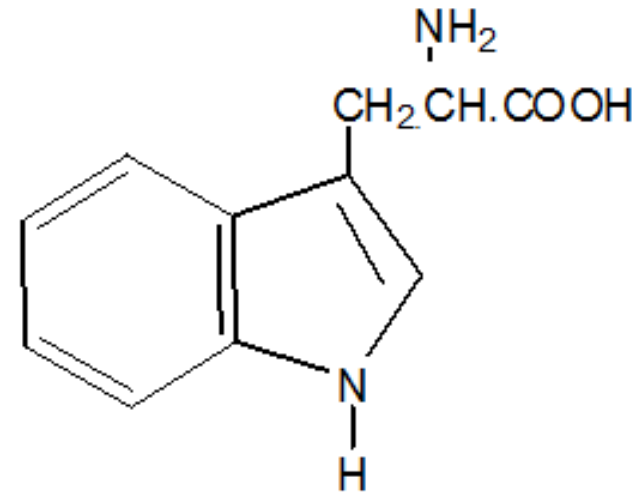

Fig. 3: Tryptophan.

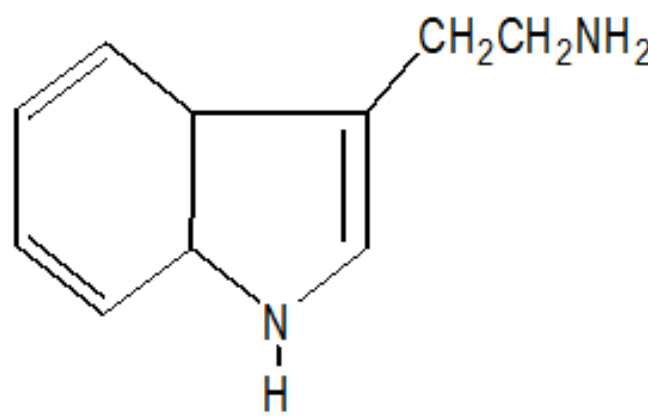

Fig. 4: Tryptamine.

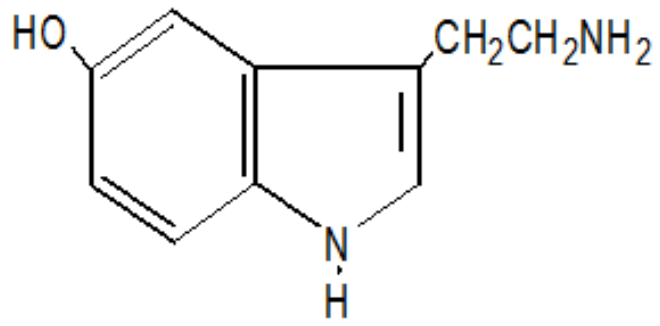

Fig. 5: Serotonin. 
Nitrogen containing heterocycles play a vital role in the field of medicinal industry. Mechanistically interesting Arylidene-1, 3indandione adduct (Figure-6) synthesized from 2-arylidene-1, 3indandione and hydrazine followed by subsequent dehydration has been found to have bactericidal and fungicidal activity (Osman.S.A.M.et.al1988)

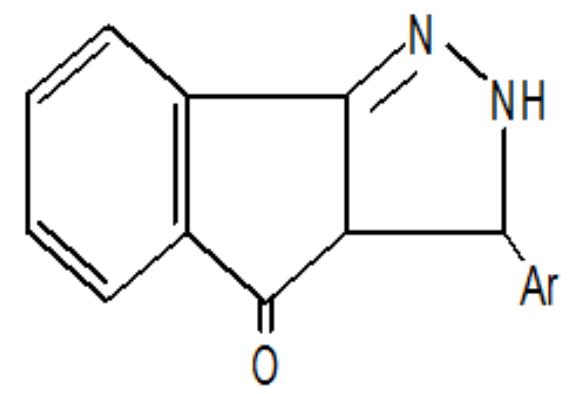

Fig. 6:

Exhaustive literature survey revealed that no mechanism for the formation of this compound has been discussed earlier,Therefore, the plausible mechanism proposed for the formation of (6) can be depicted as below.Scheme-1.

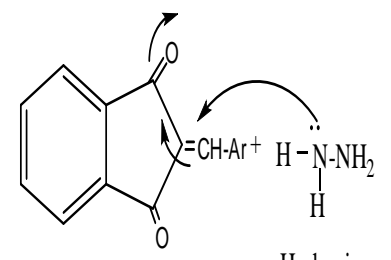<smiles>C=C</smiles><smiles>CCC1=C(OCCN)c2cccc3cccc(c23)C1=O</smiles>
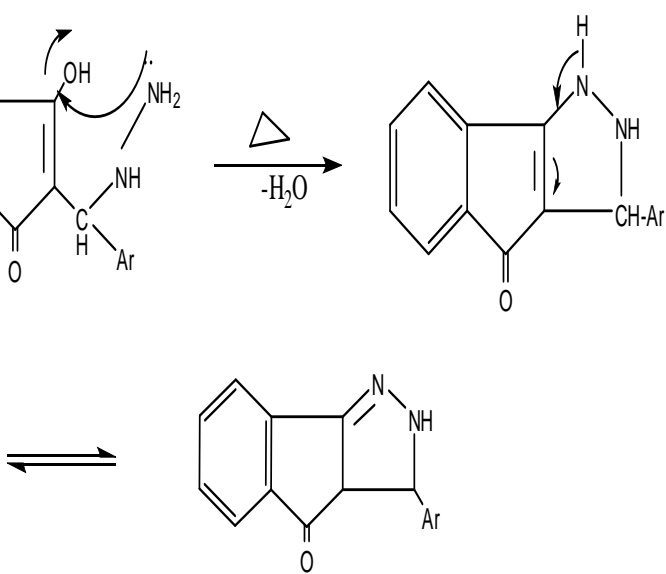

(6)

An important nitrogen containing tetracyclic compound (Figure7), of immense pharmaceutical interest has also been synthesized from 2-arylidene-1,3-indandione with 2-aminothiazoles (Ablak;et.al 1992).<smiles>O=C1C2=C(N=C3SC=CN3C2c2ccccc2)c2ccccc21</smiles>

Fig. 7:

However, the compound is known but literature records no evidence for its mechanism. Thus, the mechanism proposed for the

formation of (7) can be explained on the basis that the amino group of 2-aminothiazole reacts with the electron deficient carbon of arylidene - 1, 3-Indandione followed by cyclization and subsequent loss of water forms the main product (7). Scheme-2.

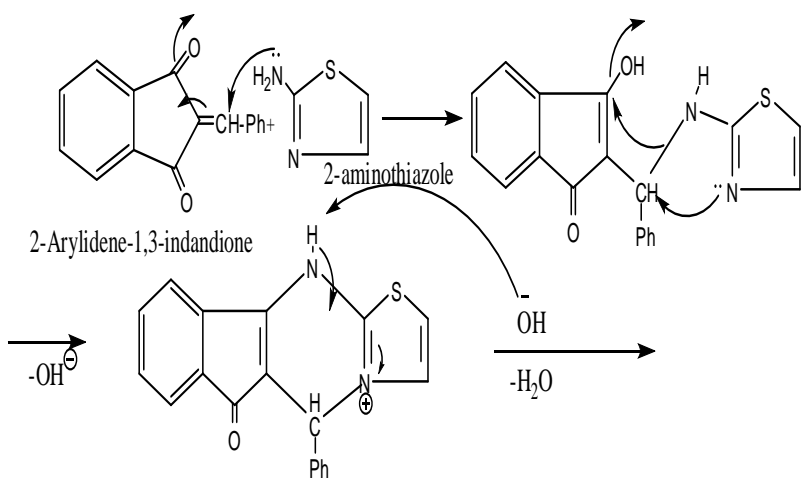<smiles>O=C1C2=C(N=C3SC=CN3C2c2ccccc2)c2ccccc21</smiles>

Scheme. 2:

Kinetic assessment of N-hydroxymethyl derivatives (Figure-8) of nitrogen heterocycles has been studied as possible prodrugs (Khan.M.N.1990)

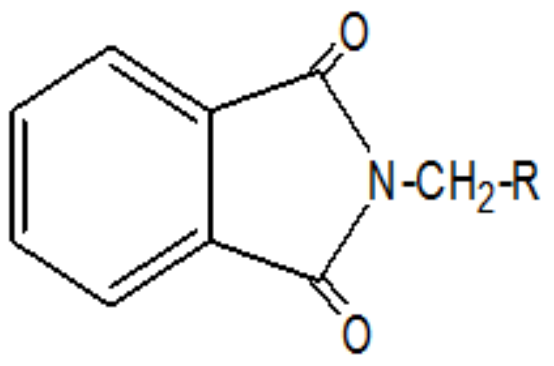

Fig. 8:

Some non-steroidal anti-inflamatory carboxylic acid drugs have been treated with $\mathrm{N}$-hydroxymethyl phthalimide to get esters of the type (Figure-9) which have been evaluated as potential prodrugs with the aim of depressing the gastrotoxicity of parent drugs(Omar.A.F 1998)

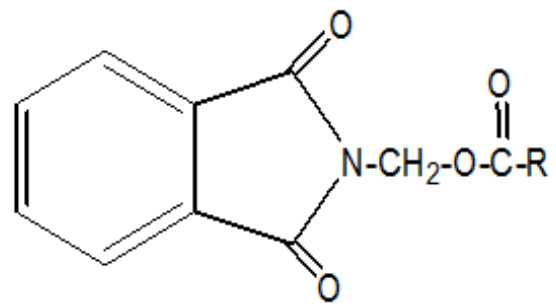

Fig. 9:

Phthalimide derivatives (Figure-10) synthesized from phthalimide with hydrazones have been found as potent insecticides.(Ebihara.K.et.al JP.08, 245, 585, [96,245,585]). 
<smiles>[R]C=NN1C(=O)c2ccccc2C1=O</smiles>

Fig. 10:

Mechanistically the formation of (10) can be explained as below.Scheme-3.

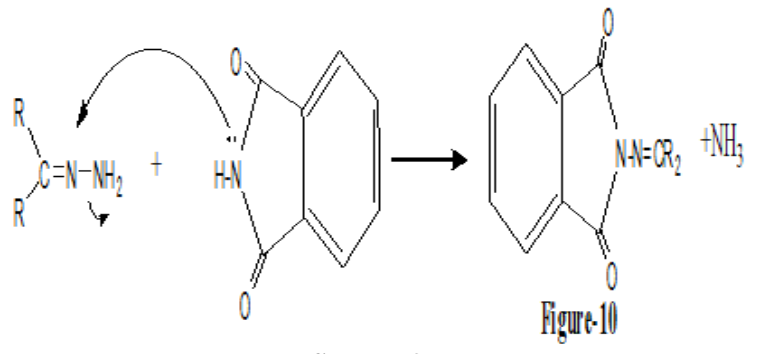

Scheme 3:

Phthalimides and their related 3-alkyl and 3-aryl methylene-2,3dihydro- $1 \mathrm{H}$ isoindoline-1-ones have been found to play an important role In medicinal chemistry dueto a wide range of therapeutic applications (Kushwanta.N et.al 2016,Bhatia.R.K 2017,Csende.F et.al 2005, Frlan.R et.al 2017 and Csende.F.et.al 2012).

4-aroyl-6-alkyl(aryl)-pyradazin-3 (2H)-one (Figure-Q),an important $\mathrm{N}$-heterocycle leads to mechanistically interesting chemoselective synthesis of a wide range of products when interacted with different substrates (Soliman .A.A et.al 1989).Scheme4.

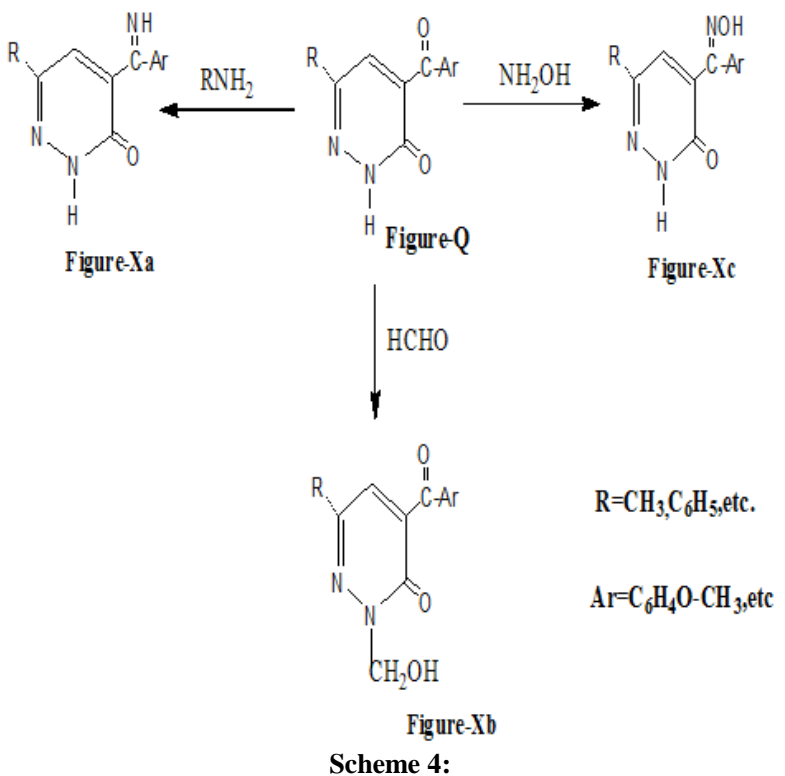

Mechanistically the formation of (Figure-Xa) can be rationalized as below (Scheme-5).

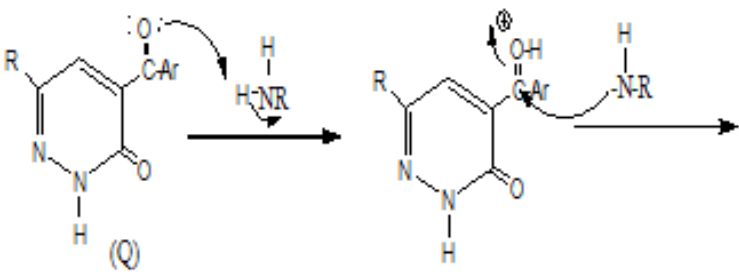<smiles>[R]c1cc(C(C)O)c(=O)[nH]n1</smiles>

Scheme 5:

Plausible mechanism proposed for the formation of $(\mathrm{Xb})$ can be explained as below. Scheme-6.

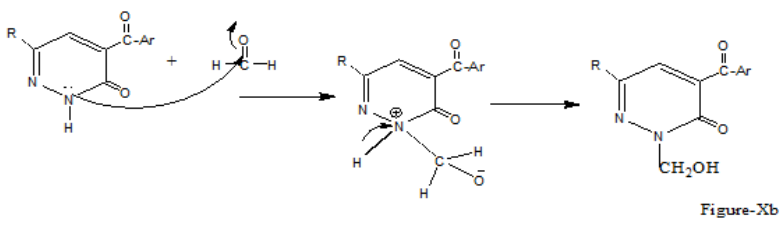

Scheme 6:

Morphine (Figure-11), a nitrogen containing opium alkaloid is an analgesic that relieves pain without causing unconsciousness but has some serious side effects. It is addictive and can cause nausea, a decrease in blood pressure and depressed breathing rate.

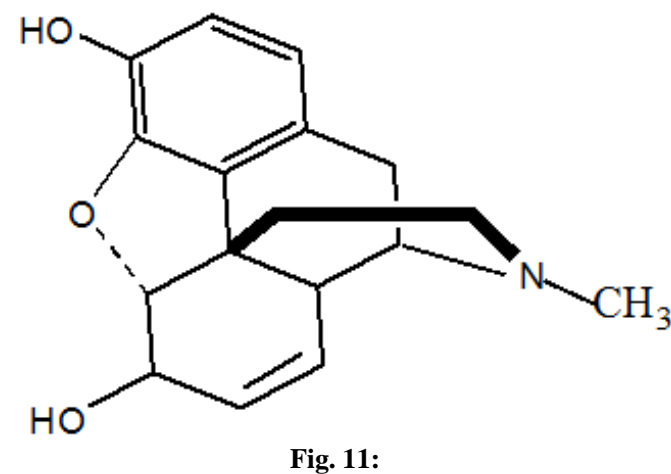

Reserpine an important alkaloid of Rauwolfia species lowers the blood pressure and is used to calm schizophrenics and improve their accessibility to psychiatric treatment. Fentanyl (Figure-12), a nitrogen heterocycle is a very short acting drug about 100 times as potent as morphine.It is used as an anaesthetic in about $70 \%$ of surgigical procedures.

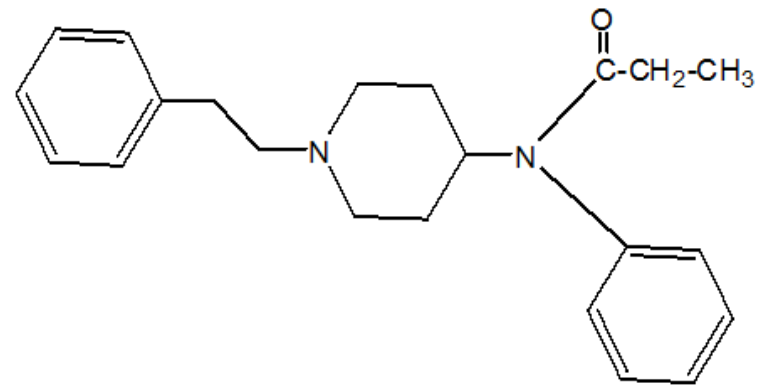

Fig. 12: 
2-aryl quinoline-4-amine (Figure-13) is an important heterocyclic anti-immuno-virus-1-agent(Strekowski.L.et.al 1991,Zhao.M.et.al 1994,Strekowski.L.et.al 1993 and Wilson.W.D.et.al 1992).Detailed studies have revealed that quinoline derivative (13) and its active analogs bind with RNA which has been suggested responsible for antiviral activity.

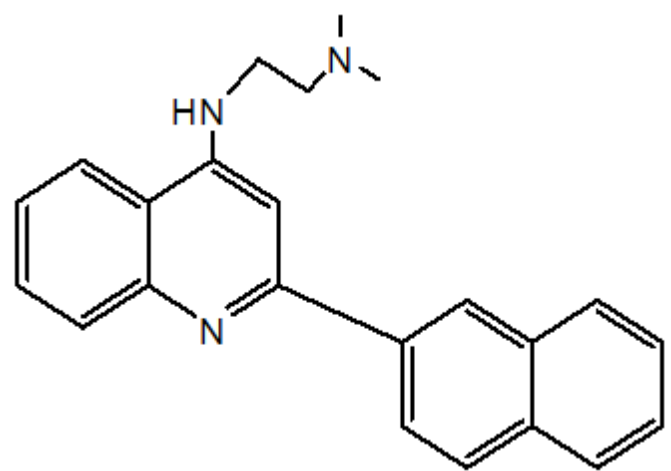

Fig. 13:

A number of 1, 2, 4 triazole derivatives have been found biologically active and possess herbicidal,pesticidal,antimicrobial and fungicidal activities.(Katrizky.A.R et.al 1984 and Pengfei.Xu.et.al 1998) .

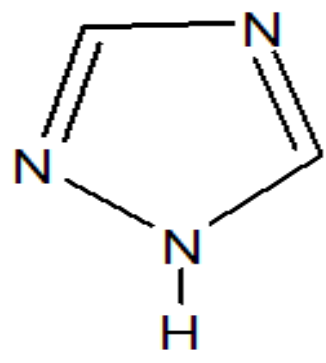

Fig. : Triazole.

Cocaine a nitrogen containing compound has been used as a local anaesthetic in different surgical procedures. Valium (Figure-14), a seven membered nitrogen heterocycle has been found medicinally important compound and is used as a mild tranquilizer.<smiles>CCCCCCC1=NCC(=O)N(C)c2ccc(Cl)cc21</smiles>

Fig. 14:

$\mathrm{N}$-heterocycles have found major applications in polymer and dye industrial sector as well. Tyrian purple (Figure-15), Mauveine A (Figure-16) and Blue Indigo (Figure-17) have been used to Impart color on fabrics.

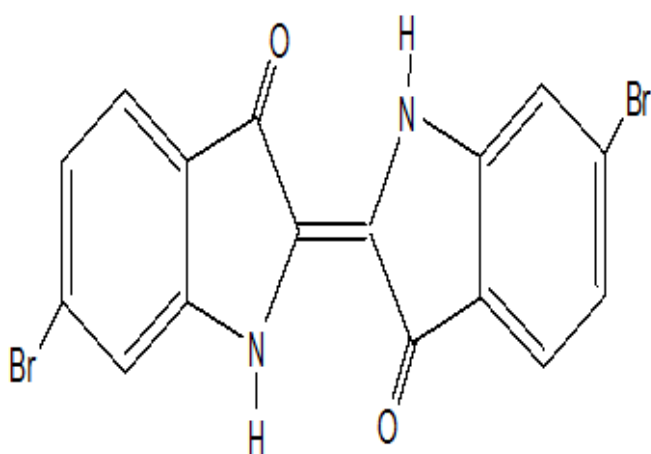

Fig. 15: Tyrian Purple.<smiles></smiles>

Fig. 16: Mauveine A

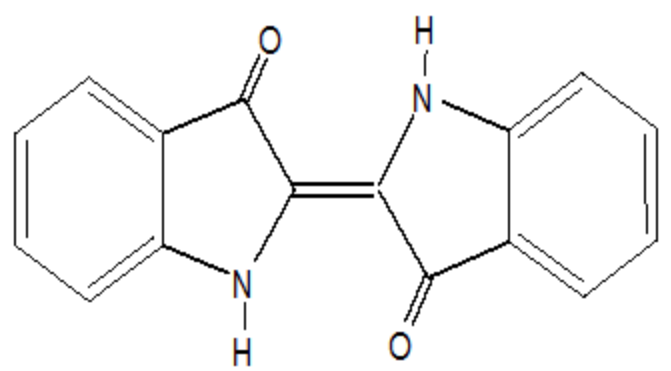

Fig. 17: Indigo.

Indigo carmine (Figure-18), a nitrogen heterocycle is a dye used for coloring food.

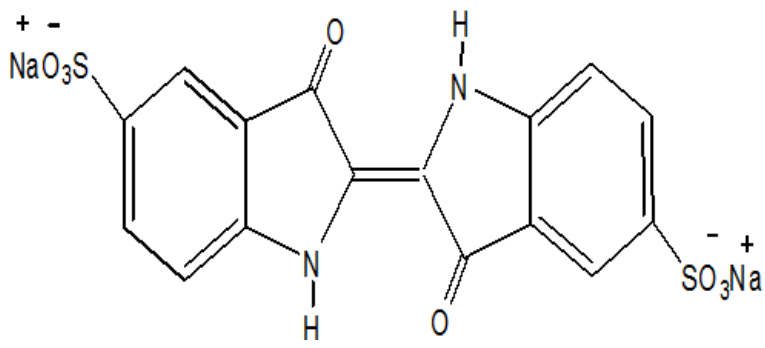

Fig. 18: Indigo Carmine.

Melamine formaldehyde nitrogen containing polymer resins (Figure-19) have found a wide range of applications in polymer industry. They are used in decorative domestic laminations on furniture,counter surfaces and as adhesives. 
<smiles>CCNc1nc(N)nc(NCNc2nc(N)nc(NCNc3nc(N)nc(NC)n3)n2)n1</smiles>

Fig. 19: Cross Linked Melamine Resin.

\section{Conclusion}

Among the heterocyclic compounds, N-heterocycles are the most studied compounds for their wider applications. Due to the presence of various active sites, $\mathrm{N}$-heterocycles have been easily converted to their corresponding derivatives which can be used as substrates in a series of reactions with important industrial applications, when interacted with different reagents or other compounds under varying conditions. Interesting mechanism proposed for the formation of certain compounds indicates the possible transformation of different substrates into a variety of products of significant industrial importance.

\section{Acknowledgement}

I am highly grateful to Prof.K.Z.Khan Department of Chemistry University of Kashmir and other Research Fellows for the support and inspirations that I received from them during writing this manuscript.I am also thankful to Central Library University of Kashmir for providing the necessary literature of this article.

\section{References}

[1] Thiophens and Benzothiophens,Aromatic and Heteroaromatic Chemistry Vol.7,Pocar.D,Rossi.L.M, Stradi .R and Trimarco.P,(1977);J.C.S. Perkin -1,2337.

[2] Thiophens and Benzothiophens, Aromatic and Heteroaromatic Chemistry Vol.7,Oe.K,Tashiro.M and Tsuge.O,(1977);Bull.Chem.Soc.Japan,50,3281).https://doi.org/10.1 246/bcsj.50.3281.

[3] Indoles, Aromatic and Heteroaromatic Chemistry, Decodts.G; (1976). Bull.Soc.Chim.France, 1839.

[4] Abika.M, Kosugi.Y and Takada.T, (1977); Heterocycles, 6, 1125 View at Google scholar/View at publisher.

[5] Aromatic and Heteroaromatic Chemistry,Takada.T, Kosugi.Y and Akiba.M (1977); Chem. and Pharm. Bull. (Japan), 25,543.

[6] Heterocyclic Compounds, Organic Chemistry;Finar.I.L,(1986) The Fundamental Principles( $6^{\text {th }}$ edition), Vol.1,826-864.

[7] Indazoles,Five membered Ring Systems, Suschitzky.H and MethCohn.O (1979) ;Aromatic and Heteroaromatic Chemistry, Vol.7,55

[8] Self-Assembly of Selected 5, 10, 15, 20 Tetraarylporphyrins,Anderson.H.L (1999);Chem.Comm. 23232330

[9] Self-Assembly of

Selected

$5,10,15,20$ Tetraarylporphyrins,Loewe.J.S, Tomizaki.K, Youngblood.W.J, BO.A and Linsay.J.S (2002) ;J.Mater.Chem.12,3434-3451.

[10] [10]. Large Third-Order Optical Nonlinearity of Self-Assembled Porphyrin Oligomers Ogawa.K,Zang.T, Yoshihara.K and Kobuke.Y(2002); J.Am.Chem.Soc. 124,22-23.

[11] Functional SupramolecularChemistry,Seidel.S.R and Stang.P.J (2002);

Acc.Chem.Res.35,972-983.
[12] Stang.P.J. and Lenyuk.B.O (1997); Acc.Chem.Res.30,502-578. View at Google scholar/View at publisher.

[13] Concepts and Perspectives, Lehn.J.M (1995); Supramolecular Chemistry; VHC- Publishers, Weinhim.

[14] Noncovalent Synthesis: Using Physical-Organic Chemistry To Make Aggregates Whiteside.G.M,Simanek.E.E et.al (1995) ; Acc.Chem.Res.28,1,37-44. https://doi.org/10.1021/ar00049a006.

[15] Self-Assembling Supramolecular Complexes. Lawrence.D.S,Jiang.T and Levett.M (1995); Chem.Rev.95,6,22292260.https://doi.org/10.1021/cr00038a018.

[16] The Five-Stage Self-Assembly of a Branched Heptacatenane,Philip.D and Soddart.J.F (1996);Angew Chem.Int.Ed.Engl.35, 1154-1196. https://doi.org/10.1002/anie.199611541.

[17] Alessio.E, Lengo.E and Marzilli.L.G (2002);Supramolecular Chem.14, 103-120.View at Google scholar/View at publisher.

[18] Formation of Artificial Receptors by Metal-Templated SelfAssembly Linton.B and Hamilton.A.D(1997);Chem.Rev. 97, 5, 1669-1680. https://doi.org/10.1021/cr960375w

[19] Burrel.A.K, Wasielewski.M.R (2000);J.Porph.Phthal. 4,401.View at Google scholar/View at publisher.

[20] Susklie.K.S,Rakow.N.A ,et.al (2000) ; J.Porph.Phthal. 4,407. View at Google scholar/View at publisher.

[21] Osman.S.A.M, Yousif.N.M,Ahmad.F.H and Hamman.A.G(1988) (Pub.1990) ; Egypt.J.Chem. 31,6,727-34 (Eng.).View at Google scholar/View at publisher.

[22] EI.F.Z, Ablak and Matwally.M.A (1992); J.Serb.Chem. Soc 57,10,635-40 (Eng.).View at Google scholar/View at publisher.

[23] Khan.M.N (1990); Chem. Abst. 112,97960e.View at Google scholar/View at publisher.

[24] Omar.A.F (1998);Eur.J.Med.Chem. 33, 2,123-131 (Eng.).View at Google scholar/View at publisher.https://doi.org/10.1016/S02235234(98)80037-8.

[25] Ebihara.K, Oora.T,et.al. Jpn.Kokai, Tokkyo, Koho.JP.08, 245 , 585,[96,245,585].(Cl.CO7D 209/48). View at Google scholar/View at publisher.

[26] Recent Advances and Future Prospects of Phthalimide Derivatives,Kushwanta.N, Kaushik.D,(2016); J.Appl. Pharm.Sci. 6,159 171

[27] Isoindole Derivatives: Propitious Anticancer Structural Motifs, Bhatia.R.K (2017); Curr. Top. Med. Chem. 17, 189-207. https://doi.org/10.2174/1568026616666160530154100.

[28] Approaches to the Formation of Condensed Isoindolones,Csende.F and Stajer.S (2005) ; Curr.Org.Chem. 9, 1261-1276. https://doi.org/10.2174/1385272054863961.

[29] Frlan.R, Gobec.S (2017); Expert Opin.Ther.Pat.27, 637-641.View at Google scholar/View at publisher.

[30] Recent developments in the synthesis of heterocycle-fused isoindoles, Csende.F,Miklos .F ;et.al (2012) ; Curr.Org.Chem. 16, 1005 1050. https://doi.org/10.2174/138527212800194683.

[31] An Overview for the Chemistry of Pyridazinones , Soliman.A.A, Kandil.N.G,Sawi-EI(1989); J.Org.Chem. 19,8,779.

[32] Chemistry of the Anionically Activated Perfluoroalkyl Group in Heterocyclic Synthesis Strekowski.L, Mokroxz.R.L et.al (1991); J.Med. Chem. 34, 1739. https://doi.org/10.1021/jm00109a031.

[33] (a) Chemistry of the Anionically Activated Perfluoroalkyl Group in Heterocyclic Synthesis,,Zhao.M, Janda.L,et.al (1994) ; Biopoly mers, 34,61. (b) Strekowski.L, Wilson. W. D et.al (1993); Current Topics in Med.Chem.1, 33. View at Google scholar/View at publisher. (c) Wilson.W.D, Zhao.M, et.al (1992); Med. Chem. Res. 2,102.View at Google scholar/View at publisherhttps://doi.org/10.1002/bip.360340108.

[34] Synthesis of 1, 2, 3-Triazole-Thiazolidines and their Arylidenes as Antifungal Agent, Srivastava.S.D et.al (2002);Ind.J.Chem. Katrizky.A.R and Rees.C.W (1984); Comprehensive Heterocyclic Chemistry; Pergamon press.

[35] Pengfei.Xu,Xinping.Y, Shaozu.W and Ziyi.Z (1998) ; Ind. J.Chem. 37B, 127. (Ref.34/Google Scholar). View at Google scholar/View at publisher. https://doi.org/10.1021/ar010142d. 